\title{
Clausal complementation in Ruuli (Bantu, JE103)
}

\author{
Marie-Louise Lind Sørensen and Alena Witzlack-Makarevich \\ Åbo Akademi University and Hebrew University of Jerusalem
}

\begin{abstract}
This paper describes the morphosyntactic and semantic characteristics of clausal object complementation in the Great Lakes Bantu Language Ruuli (JE103). In addition to providing an overview of the complementation strategies in Ruuli, parallels will be drawn to constructions described for related languages as well as common cross-linguistic patterns in clausal complementation. Ruuli employs several different complementation strategies, including indicative, subjunctive, and infinitive constructions. Complement clauses can be either unmarked or marked with a complementizer, the most common of which is nti. These two options are also available for direct speech. Other less common complementizers, which cannot be used to introduce direct speech complements include $o b a, n g a$ and $n i$. As individual complement-taking predicates do not allow for every complementation strategy, we will explore the semantic and morphosyntactic conditions which predict the choice of complement. To this end, we consider several predictors. We investigate the restrictions imposed by various complement-taking predicate types, e.g. knowledge predicates, phasal predicates and utterance predicates. Then we consider whether the complement expresses a proposition (a truth-valued meaning unit) or a stateof-affairs (a non-truth valued meaning unit) and whether the subject arguments in the two clauses are identical.
\end{abstract}

Keywords: Ruuli, Bantu languages, complementation, semantics

\section{Introduction}

This paper ${ }^{1}$ deals with clausal object complementation in the Great Lakes Bantu language Ruuli (also known as Ruruuli-Lunyala, ISO 639-3: ruc; JE103). We will analyze the features of the morphosyntactic and semantic characteristics of Ruuli complementation and compare them to those of other Bantu languages as well as to common cross-linguistic patterns in clausal complementation. Ruuli employs several different complementation strategies, including indicative, subjunctive, and infinitive constructions. Complement clauses can be either unmarked or marked with a complementizer, the most common of which is nti. These two options are also available for direct speech. Other less common complementizers are $o b a, n g a$ and $n i$, which cannot be used to introduce direct speech. As individual complement-taking predicates do not allow for every complementation strategy and have preferences for specific complementation strategies, we will explore the morphosyntactic and semantic conditions which predict the choice of complement. To this end, we consider several predictors. We investigate the restrictions imposed by various complement-taking predicate types, e.g. knowledge predicates, phasal predicates and utterance predicates. Then we consider whether the complement refers to a proposition (a truth-valued meaning unit) or a state-ofaffairs (a non-truth valued meaning unit) and whether the subject arguments in the two clauses are identical. We also consider the polarity of the two clauses

The paper is structured as follows. Section 2 provides a typological overview of clausal complementation. Section 3 gives an introduction to the morphosyntax of the Ruuli language, as

\footnotetext{
${ }^{1}$ We are grateful to Kasper Boye and Saudah Namyalo for providing valuable feedback on the first draft of this paper.
} 
well as outlines the sample and methods used in the present study. Section 4 describes the main complement types in Ruuli. Section 5 analyzes the distribution of different complement types relative to different semantic classes of complement-taking predicates. Section 6 discusses the main predictors of complement choice. A conclusion and outlook follows in Section 7.

\section{A typological overview of clausal complementation}

This section provides a brief overview of central morphosyntactic and semantic features of clausal complementation from a cross-linguistic perspective and serves as a preliminary to placing the complementation strategies found in Ruuli in a broader typological context. We review definitions of complement clauses and complementation strategies in Section 2.1, complement-taking predicates in Section 2.2, aspects of complement verb forms (e.g. TAM-marking) in Section 2.3, complementizers in Section 2.4, as well as the semantic distinction between states-of-affairs and propositions in Section 2.5.

2.1 Complement clauses and complementation strategies. Complement constructions have been defined in both syntactic and semantic terms. In studies based on semantic definitions, terms such as complement relations and complementation strategies tend to be preferred over complement clauses. Syntactic definitions of complement constructions define complement clauses as core syntactic arguments (i.e. subject or object) of complement-taking predicates in clausal form (as opposed to NP-complements) (Dixon 2006: 15). On this account, clauses such as the one in brackets in (1) can be described as a complement clause, because it functions as the object of the matrix clause she thinks.

\section{She thinks [they are gone].}

Semantically-oriented analyses of complement constructions, on the other hand, define complements as semantic (rather than syntactic) arguments of complement-taking predicates (Noonan 2007: 52) and in terms of the relationship between two states-of-affairs Cristofaro (2003: 95). The motivation for the latter definition, in particular, is that definitions of complement clauses as syntactic arguments is too narrow for typological purposes and implies that complements are syntactically embedded. English complement clauses, like the one in (1), can be analyzed as embedded syntactic arguments of a complement-taking predicate, and similar constructions exist in other languages. However, complements in certain other languages cannot be described as embedded, even though they express similar semantic relations. A case in point are languages in which reported speech constructions are ambiguous between direct reported speech and indirect reported speech. Although direct reported speech is not a syntactic argument of a complementtaking predicate and therefore would not traditionally be analyzed as a complement clause, functionally it constitutes a complement relation (Cristofaro 2003, 2013) or a complementation strategy (Dixon 2006: 6-9).

Because of the existence of constructions which are arguably instances of complementation, despite not being syntactic arguments, Cristofaro (2003: 95) prefers the term complement relations which she defines as a situation where two states-of-affairs are linked "such that one of them (the main one) entails that another one (the dependent one) is referred to." (cf. Section 2.5 below on states-of-affairs vs. propositions). The advantage of this definition is that it functionally covers complement relations in all languages, while remaining compatible with the definition in terms of syntactic argument status.

In this article we adopt this broader conception of complementation in order to provide the most comprehensive description of the structure and semantics of complementation in Ruuli. The analysis will thus cover more traditional examples of complement constructions as well as reported speech, which would be excluded under a narrow syntactic definition of complement clauses. In 
what follows, we use the term complement to refer to clausal semantic arguments of complementtaking predicates, including infinitives, as well as reported speech.

2.2 Complement-taking predicates. In cross-linguistic studies of complementation, a number of complement-taking predicate classes have been identified. Commonly identified classes include modal predicates (e.g. can, may), phasal predicates (e.g. begin, continue), manipulative predicates (e.g. force, make), desiderative predicates (e.g. want, wish), perception predicates (e.g. see, hear), knowledge predicates (e.g. know, forget), propositional attitude predicates (e.g. think, believe) and utterance predicates (e.g. say, ask) (Ransom 1986, Givón 2001, Cristofaro 2003, Dixon 2006, Noonan 2007).

Existing cross-linguistic classifications of complement-taking predicates are typically based on a combination of predicate semantics and the type of complement that occurs with a given complement-taking predicate. A downside of such classifications is that they downplay the fact that certain predicates - such as see, know and tell in English - can take more than one complement, as pointed out by e.g. Ransom (1986), Verspoor (2000), Boye (2012) and Serdobolskaya (2016). Consider the contrast between the gerund and the indicative complement of see in example (2).

a. She saw him playing the piano.

b. She saw that he played the piano.

The term perception predicate would be used to describe complement-taking predicates, such as see, only in cases when they occur with a complement describing direct perception, as in (2a). In contrast, see in (2b) would be described as a knowledge predicate. This classification might have the unwanted side-effect of language-specific descriptive studies focusing only on directperception constructions with complement-taking predicates meaning 'see' and overlook other complement types used with the same predicate. In the analysis of Ruuli, we make an attempt at highlighting contrasts such as the one in (2), as we describe the distribution of complement types over different predicate classes.

2.3 Complement verb forms. Typical contrasts between complement verb forms include contrasts between those forms that can be described as finite vs. non-finite ones or between balanced vs. deranked ones (cf. Stassen 1985, Cristofaro 2003). Balanced verbs are verbs that correspond to verbs in independent declarative clauses with regards to TAM-marking and/or agreement, while deranked verbs are verbs that are different from verbs in an independent declarative clause in some way in terms of tense, aspect, mood or person agreement or by having markers that are not found in independent declarative clauses (Cristofaro 2013). In contrast to Stassen (1985), Cristofaro (2003: 57) furthermore considers a number of moods, such as subjunctives and hortatives, to be deranked by default.

Languages vary considerably as to whether - and to what extent - TAM-marking is obligatory on complement verbs. On one end of the spectrum, there are verbs that need to be marked for the exact same TAM-categories as verbs in independent clauses. On the other end of the spectrum, there are verbs that do not allow any of the TAM-marking available to an independent clause verb. In intermediate cases, verbs may display a large number of TAM-markers, even when the complement does not allow all of the TAM-markers possible for an independent clause verb. In the latter case the complement would still be considered deranked in the sense of Cristofaro (2003), but finite in traditional terms.

2.4 Complementizers and quotatives. Another important point of variation in complementation is the distribution and function of complementizers. According to Noonan (2007: 55), a complementizer is "a word, particle, clitic or affix, one of whose functions it is to identify [a clause] as a complement", such as English that and whether. Diachronically, complementizers are often derived from elements such as demonstratives or case markers and more rarely from verbs (Heine 
\& Kuteva 2002, Dixon 2006, Noonan 2007). In deviation from the cross-linguistic tendency, complementizers in Bantu languages are rather frequently derived from speech verbs but can also have other sources, such as personal pronouns (Kawasha 2007: 181).

While some languages have rich systems of complementizers expressing many different morphosyntactic and semantic features, other languages have few complementizers or lack them altogether. In addition to identifying a clause as a complement, complementizers may have additional semantic functions, for instance modal functions, indicating epistemic certainty or uncertainty (Frajzyngier 1995, Frajzyngier \& Jasperson 1991), or the function of distinguishing between propositions (truth-valued meaning units) and states-of-affairs (non-truth valued meaning units) (Kehayov \& Boye 2016a: 812-818, cf. Section 2.5).

The identification of complementizers in any individual language is complicated by the fact that a candidate for complementizer status might also function as e.g. a relativizer or adverbializer or it might be synchronically identifiable as an adverb, verb or noun (Kehayov \& Boye 2016b: 83).

The term quotative rather than complementizer is sometimes encountered in analyses of complementation. $^{2}$ This term is often used for complementizers that introduce direct reported speech - probably motivated by the fact that within some analytical approaches to complementation, direct reported speech is not considered a type of complement. In languages with a complementizer that only occurs with direct reported speech introduced by an utterance predicate, this can make sense. However, if the so-called quotative is also found with other complement-taking predicate types and/or with indirect reported speech (or complements that do not report speech at all for that matter), the line between quotatives and complementizers begins to blur. As Güldemann (2008: 456) concludes, there is generally "no principled distinction between a quotative and a complementizer". In the remaining part of the paper, we will use the term complementizer to cover a morpheme which as one of its functions introduces the following clause as a complement no matter whether the complement can be characterized as reported speech or not.

2.5 Complement semantics. A central motivation for complement contrasts, such as finiteness or balancing-deranking contrasts and complementizer contrasts, is the semantic contrast between states-of-affairs and propositions ${ }^{3}$. The contrast has traditionally been understood as a contrast between non-truth valued and truth-valued meaning units (but see Boye 2012 and the references therein for alternative cognitive-functional analyses). The terms states-of-affairs and propositions are also known as actions and facts (Lees 1960), second-order entities and third-order entities (Lyons 1977), and events and propositions (Palmer 1979, Perkins 1983). This distinction plays a central role in functional frameworks such as Functional Grammar (Hengeveld 1989) and has been shown to be analytically applicable to a number of genealogically unrelated languages across the world. Language-specific studies include analyses of clausal complementation in Mayan languages (e.g. Schüle 2000 on Akateko), Japanese and Korean (e.g. Horie 2000), Indo-European (e.g. Holvoet 2016 on Latvian), and Turkic languages (e.g. Rentzsch \& Mitkovska 2017 on Balkan and Standard Turkish).

Examples (3)-(5) illustrate some morphosyntactic contrasts in English that have been linked to the semantic contrast between states-of-affairs and propositions. In (3a) see takes a finite complement and is used in the sense of acquisition of knowledge (also called indirect perception), while in (3b), see takes a non-finite complement and is used in the sense of direct/immediate perception. The complement in (3a) expresses a proposition, whereas the complement in (3b) expresses a state-of-affairs (Dik \& Hengeveld 1991, Boye 2010).

\footnotetext{
${ }^{2}$ Note that the same term has also been used to describe items that are not complementizers, but rather reportive evidentials (also known as "hearsay-markers"), cf. Boye (2012: 20).

${ }^{3}$ The role of the contrast between states-of-affairs and propositions in complement clause constructions crosslinguistically is extensively discussed in Sørensen (2018).
} 

a. She saw that he played the piano.
b. She saw him playing the piano.

In (4a), know has the sense of knowledge of information, which can be called epistemic knowledge, and the finite complement expresses a proposition, while in (4b), know has the sense of knowledge of how to do something, which can be called action knowledge, and occurs with a nonfinite complement expressing a state-of-affairs (cf. Sørensen \& Boye 2015).

\section{a. She knows that he plays the piano. \\ b. She knows how to play the piano.}

In (5a), tell introduces a finite complement and is used to report on an assertion expressing a proposition, whereas in (5b), tell describes an order or request and occurs with a non-finite complement expressing a state-of-affairs.

\section{a. She told him that they played the piano.}

b. She told him to play the piano.

The English predicates see, know and tell all occur with both state-of-affairs and propositional complements, as exemplified in (3)-(5). However, in other languages that make a morphosyntactic distinction between states-of-affairs and propositions, complement-taking predicates need not be polyfunctional in this respect. Instead some languages employ different complement-taking predicates to introduce propositional and states-of-affairs complements. We will make reference to this distinction throughout the paper and in Section 5, as well as exemplify contrasts between states-of-affairs and propositions within different semantic classes of predicates.

Cross-linguistically there is a great deal of variation in the morphosyntactic properties of complement constructions and a given languages may employ several complementation strategies, each with its own semantic and distributional properties (Noonan 2007). On the other hand, there are also recurrent semantic patterns, such the contrast between states-of-affairs and the semantic classification of predicates, that have proven useful for the analysis of most languages.

\section{Ruuli}

Ruuli (or Ruruuli-Runyala, JE103, ISO 639-3: ruc) is a Great Lakes Bantu language mainly spoken in the Nakasongola and Kayunga districts of central Uganda. Following Schoenbrun (1994), Hammarström et al. (2018) classify Ruuli as a West Nyanza/Rutara language of the Great Lakes Bantu group of languages. However, it should be noted that Schoenbrun's genealogical study did not include any data from Ruuli as there were none available at the time (Schoenbrun 1994: 118119).

The number of ethnic Baruuli and Banyara is around 237,000 according to the 2014 census (Uganda Bureau of Statistics 2016), but the actual number of Ruuli speakers is probably lower as the young population often does not speak the language (Nakayiza 2013). Most speakers of Ruuli are multilingual. In addition to often being fluent in Ganda (West Nyanza/North Nyanza, JE.15, the dominant language of the area) and English (the official language of instruction in Uganda), many speakers interviewed for the corpus used in the present study indicated that they also speak other, mostly Bantu languages of Uganda.

Ruuli is a typical Bantu language: The dominant constituent order is SVO. Nominal and verbal inflectional morphology is primarily prefixing. Nominal morphology is characterized by a system of noun class prefixes. Every noun in singular and plural is assigned to one of twenty noun classes numbered from 1 to 23. The class numbers correspond to the reconstructed Proto-Bantu classes with their respective noun prefixes and are used to label noun classes in all Bantu languages 
(see Van de Velde 2019: 237-239 and the references therein). Most nouns have both singular and plural forms and these belong to two different noun classes. As in many other Bantu languages, the odd-numbered classes 1,3, 5, 7, and 9 contain singular nouns and their corresponding plural forms usually belong to the evennumbered classes $2,4,6,8$, and 10 , respectively. To enhance readability we do not segment nominal prefixes on nouns in the examples and indicate noun classes in brackets, as e.g. on nkodoore 'francolin(9)' in (6), which has a nasal prefix of class 9 realized here as $n$-.

The nominal class determines the shape of the agreement prefixes on dependents in a noun phrase, on the verb, as well as on a number of other constituents. We indicate the class agreement prefixes on dependents by segmenting them and providing the respective class number in Arabic numerals, as in the case of the object index $l i$ - ' 50 ' on the verb in (7). We also use Arabic numerals to indicate person indexing on the verb and person information on pronouns. Notice that in these cases the Arabic numerals are always followed by the indication of number ( $\mathrm{sg}$ or pl), for instance, both on the verb and the pronoun in (6). As in some Bantu languages, the noun-class prefixes in Ruuli are often preceded by another prefix - the so-called augment (cf. Van de Velde 2019: 247255). The verb in Ruuli has about nine prefix slots and five suffix slots (the final analysis of the verb morphology is still pending). The verb of an independent clause obligatorily indexes its subject, as in (6), as well as optionally its object, as in (7).

$\begin{array}{lll}\text { ǹjé } & \text { ńdyà } & \text { ǹkódóòrè } \\ \text { nje } & \text { n-li-a } & \text { nkodoore } \\ \text { 1sg } & \text { 1sgS-eat-FV } & \text { francolin(9) } \\ \text { 'I eat a francolin.' } & \end{array}$

$\begin{array}{llll}\text { nàyé } & \text { ǹjé } & \text { éísùmù } & \text { nàlìzwì̀rékù } \\ \text { naye } & \text { nje } & \text { e-isumu } & \text { n-a-li-zw-iire=ku } \\ \text { but } & \text { 1sg } & \text { AUG-spear(5) } & \text { 1sg-PST-5O-leave-APPL.PFV=17.LOC } \\ \text { 'But I abandoned the spear.' } & \end{array}$

Like many other Bantu languages, Ruuli is a tonal language. At present, the tonal system of Ruuli is being investigated and many tonal processes pertaining to the level of word and phrase are still poorly understood and the relations between underlying and surface tone remain opaque in many cases. In what follows we indicate only surface tone in the first line of every example. ${ }^{4}$ This line also captures some regular phonological alternations not represented in the second line which represents the underlying form and closely follows the accepted orthography.

The data used in the present study come from Witzlack-Makarevich et al. (2019). ${ }^{5}$ Before the beginning of this project no description of Ruuli existed. As of May 2018 the corpus contained about 150,000 words of naturalistic speech (transcribed and translated). Further 50,000 were available from digitalized written resources produced by the speakers' community. We first sampled about 1,000 tokens of complementation by exhaustively identifying all potential complementation strategies and complement taking verbs in a number of texts. These 1,000 tokens were annotated for such variables as the presence and form of complementizers, polarity of the two clauses, the identity of subjects in the two clauses, the semantic class of the complement-taking predicates, etc. Once the major complement-taking predicates and complementation strategies were identified and an initial hypothesis about their distribution was made, we sampled further tokens (about 500) of less common complement-taking predicates and complementation strategies. These data were supplemented by focused elicitations carried out in June 2018.

\footnotetext{
${ }^{4}$ We are grateful to Anatole Jesero and Saudah Namyalo for reeliciting the examples used in this article and annotating surface tone.

${ }^{5}$ The corpus collected within the project A comprehensive bilingual talking Luruuli/LunyaraEnglish dictionary with a descriptive basic grammar for language revitalisation and enhancement of mother-tongue based education (PI Saudah Namyalo, 2017-2020, funded by Volkswagen Foundation).
} 


\section{Complementation in Ruuli}

In this section we will describe and exemplify the complement types found in Ruuli. There are three main complement types, given in (8).

Complement types

a. indicative complements ( $\operatorname{suffix}-a$ )

b. subjunctive complements ( $\operatorname{suffix}-e$ )

c. infinitive complements (class 15 prefix with the respective augment $(o) \mathrm{ku}-)$

This distinction between indicative, subjunctive and infinitive complements is typical for Bantu languages and there is furthermore a strong tendency for it to be expressed in morphologically similar ways across individual languages (Myers 1975: 185), i.e. as affixes that are identical or nearidentical to $-a$, $-e$ and $(o) k u$ - in Ruuli. In Ruuli the most frequent and versatile complement type is the infinitive, which occurs with all classes of complement-taking predicates except for perception predicates (see Section 5).

More diversity is found between individual Bantu languages when it comes to the form, distribution and function of complementizers. In Ruuli there are three major complementizers, given in (4). Complementizers mark indicative complements only.
Complementizers
a. $n t i$
b. oba
c. nga

In sections 4.1-6.1 we consider each individual complement type and complementizer in turn. In Section 4.7 we furthermore consider an additional potential candidate for complementizer status, $n i$. Reported speech and another minor complementizer $m b u$ will be considered in Section 5.9 .

Complements generally follow the complement-taking predicate. However, on rare occasions, complements precede the complement-taking predicate, as in (10).

$\begin{array}{lc}\text { tìbìkyátúkòlá } & \text { ńdówòòzá } \\ \text { ti-bi-kya-tu-kol-a } & \text { n-dowoz-a. } \\ \text { NEG-8S-PERS-1plO-work-FV } & \text { 1sgS-think-FV } \\ \text { 'They no longer work for us, I think.' }\end{array}$

In this case, however, lowooz 'think' is arguably a parenthetical verb rather than a complement-taking predicate, $\mathrm{cf}$. the discussions of parentheticals vs. complement-taking predicates in Thompson (2002), Boye \& Harder (2007) and Newmeyer (2015). Such constructions will therefore be exempt from our analysis of Ruuli complementation.

4.1 Indicative complements. The verb form in indicative complements corresponds to that of the verb in an independent declarative clause. The verb obligatorily indexes the subject and optionally the object and can occur with any TAM-categories the verb in an independent clause can occur with. It is negated in the same way verbs in independent clauses are negated. Indicative complements follow perception predicates, knowledge predicates, propositional attitude predicates and utterance predicates and can be marked by a complementizer (nti, oba or nga, cf. Sections 4.4, 4.5 and 4.6, respectively). Examples of indicative complements can be found throughout the article, e.g. (37b), (38), (43), and (58a). 
4.2 Subjunctive complements. The subjunctive in Ruuli is formed by adding the suffix $-e$ to a verb stem replacing the final vowel $-a$. Both the form and the function of this suffix are similar to the cognate ones in closely related Great Lakes Bantu languages (Nurse \& Muzale 1999), as well as in many other Bantu languages (Nurse 2008: 44, 192). Final $*_{-} e$ has also been reconstructed for Proto-Bantu (Meussen 1967).

In Ruuli independent clauses the subjunctive is used to express hortative, optative and modal meanings, as in (11).
a. tùsómè ${ }^{\downarrow}$ syé
ábáànà
tu-somesy-e
a-baana
1pls-teach-SBJV
AUG-child(2)
'Let us educate children.'
b. ókátòndá àtújù ${ }^{\prime}$ né
o-Katonda a-tu-jun-e
AUG-god(1) 1s-1plo-help-SBJV
'May god help us.'

Similarly to the finite indicative forms (Section 4.1) and in contrast to infinitives (Section 4.3), the subjunctive shows obligatory subject agreement, as in (4.2). In contrast to the finite forms, the subjunctive is not marked for either tense or aspect.

In complement constructions, the subjunctive is found with modals, desideratives and utterance predicates. Complements with subjunctive verbs are never marked by complementizers. Subjunctives occur both in same-subject (12a) and different-subject (12b) constructions.

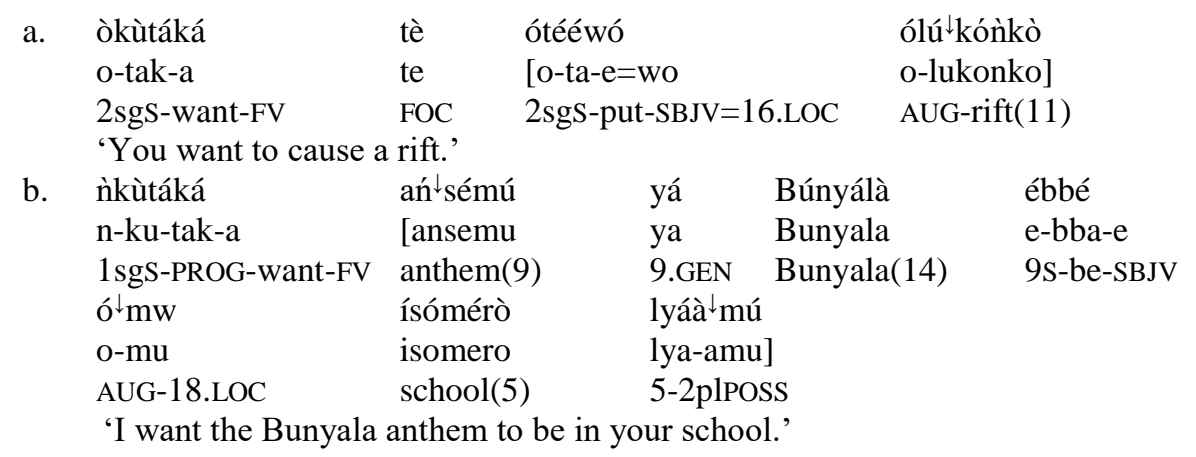

4.3 Infinitive complements. The infinitive is formed by adding the class 15 prefix $k u$ - to the verb stem (followed by a final vowel). The class 15 infinitive morpheme *ku is reconstructed for ProtoBantu (see Nurse 2008: 141) and is found in many other Bantu languages, e.g. in the closely related Soga (Nabirye2016: 309) and Nkore-Kiga (Taylor1985: 20). The prefix $k u$-is realized as $k w$ - when the following verb stem begins with a vowel.

In most instances, the respective augment prefix $o$ - precedes the class 15 prefix $k u$-, as with $o-k u$-emb- $a$ 'to sing' in (13). The distribution of $k u$-vs. $o-k u$ - cannot be described definitively as of now, but one generalization is worth noticing: With negated complement-taking predicates only $\mathrm{ku}$ occurs. However, when the complement-taking predicate is not negated, both $o-k u$ - and $k u$ - are possible. $^{6}$

\footnotetext{
${ }^{6}$ This is different from some other Bantu languages, which reportedly show free variation between $o-k u$ and $k u$ infinitives. Describing Nkore-Kiga, for example, Taylor (1985: 28) notes that "[t]he form $k u$ is normal, and $o-k u$ gives a more general force".
} 
(13)
nyèndyá
n-endy-a
mùnó
muno
1sgs-like-FV
much

'I like to sing very much.'
ábántú
tìbàkyáyé ńdyá $^{2}$
kúkòlà
a-bantu
ti-ba-kya-endy-a
[ku-kol-a]
AUG-person(2) NEG-2S-PERS-want-FV
INF-work-FV
'People no longer want to work.'

The infinitive does not show subject indexing and does not take any TAM marking. On the other hand, the infinitive can index objects, as well as take valency-changing affixes, as in (15). The infinitive can be negated with the prefix ta-. Additionally, instead of the regular class 15 prefix $\mathrm{ku}$-, negative infinitives take class 14 prefix $b u$, frequently accompanied by the respective augment $o$-, as in (16).
nìbàtáká ókútùbàn ${ }^{\downarrow}$ dísyá
[o-ku-tu-band-isy-a
òkáwúmúpúlì
ni-ba-tak-a
o-Kawumpuli

"They wanted to make us worship Kawumpuli.'
òmúsàìà
àyíńzá
óbúttáléétàwò
mùkàlì
o-musaiza
a-yinz-a
[o-bu-ta-leet-a=wo
mukali]
AUG-man(1) 1s-be.able-FV
AUG-INF-NEG-bring-FV=16.LOC
wife(1)
'The man may not bring there a wife.'

The infinitive can follow all predicate types described in Section 5 below except for perception predicates, that is modals, phasals, desideratives, knowledge predicates, propositional attitude predicates, emotive predicates and utterance predicates. Infinitives are used exclusively to express states-of-affairs and occur both in same-subject and different-subject constructions, cf. Sections 5 and 6.

4.4 Complementizer $\boldsymbol{n t i}$. The most frequent complementizer in Ruuli is $n t i$, which optionally marks indicative complements introduced by perception predicates, such as 'see', as in (17a), knowledge predicates, such as 'know', as in (18a), propositional attitude predicates, such as 'think', and utterance predicates, such as 'say'. The cognate form is used in similar contexts in the closely related Ganda (Ashton et al. 1954: 93) and Soga (Nabirye 2016: 390).

Perception
a. òkúbóná
ǹtì

[nti
tètúkú ${ }^{\text {sígálá }}$
màbégáà
$\begin{array}{ll}\text { o-ku-bon-a } & \text { [nti } \\ \text { 2sgS-PROG-see-FV } & \text { COMP }\end{array}$
te-tu-ku-sigal-a
mabega]
'You see that we are not staying behind.'
NEG-1pls-PROG-stay-FV $\operatorname{back}(6)$
b. ǹjè ǹkùbóná
bùlí kímù
nje n-ku-bon-a
[buli kimwei
ómwáànà
àkúsóbólá
1sg 1sgS-PROG-see-FV every thing(7)
o-mwana
a-ku-sobol-a
ókúkìtàm ${ }^{\downarrow}$ búlyà
o-ku-ki-tambuly-a]
AUG-INF-7O-perform-FV
'I see (that) a child can perform everything.' 
(18)

Knowledge
a. òmáíté
ǹty é
íbbáàlè tùtáńdíkíré
ó kúsò ${ }^{\text {mésyá }}$
o-maite
[nti e
Ibbaale tu-tandik-ire
o-ku-somesy-a
2sgS-know.PFV COMP 23.LOC Ibbaale 1pls-start-PFV
AUG-INF-teach-FV
ábáànà
a-baana]
AUG-child(2)
'Do you know that we started educating children at Ibbaale?'
b. òmáíté yééná ádyéńdyá ókwîzùkìryá
o-maite [ye-ena a-endy-a o-ku-yizukiry-a]
2sgs-know.PFV 2-ADD.FOC 2S-need-FV AUG-INF-be.reminded-FV
'You know (that) he also needs to be reminded.'

The presence of nti does not appear to be correlated with any semantic contrast, nor does $n t i$ disambiguate direct reported speech from indirect reported speech (cf. Section 5.9): $n t i$ is equally optional with indirect reported speech, as shown in (19a), and with direct reported speech, as in (19b).
a. nàkóbá
bábígùù $\downarrow$ ré mánì
[ba-bi-gul-ire mpani]
NAR-1S-say-FV 2S-80-buy-PFV here
'He said (that) they bought them here.'
b. míbísímóólà ìswè bààtùlèètéré òkùkólá $\downarrow_{\text {séntè }}$
ni-bi-simool-a [iswe ba-a-tu-leet-ire ku-kol-a
NAR-8S-say-FV 1PL 2S-PST-1plo-bring-PFV INF-make-FV money(9)
'They said, "We were brought to make money.",

In addition to its use as a complementizer, nti can be used as a quotative particle independent of the presence of a matrix predicate, which serves to present a word as a direct quote in (20).

$\begin{array}{ll}\text { (20) ǹtì } & \text { bbé } \\ \text { nti } & \text { bbe } \\ \text { QUOT no } & \text { no "No.", } \\ & \text { (She answered) "No. }\end{array}$

4.5 Complementizer oba. A less frequent complementizer is oba. It marks indicative complements and expresses doubt towards the proposition, as in (21). This morpheme is otherwise used with the meaning 'or' to coordinate two noun phrases, verbs, and other units of the same type.

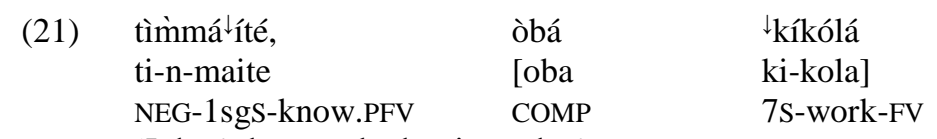

'I don't know whether it works.'

Oba is also used for indirect reports of polar questions, as illustrated in (52) in Section 5.9.

4.6 Complementizer nga. Another less frequent complementizer is $n g a$. The cognate form is reported to have a similar function in a number of related languages, see Kimenyi (2018). 


$\begin{array}{lllll}\text { ábáànà } & \text { ò̀̀zà } & \text { kùbóná } & \text { ngà } & \text { bákwî̂lkírízà } \\ \text { a-baana } & \text { o-iz-a } & \text { ku-bon-a } & \text { [nga } & \text { ba-ku-ikiriz-a] } \\ \text { AUG-child(2) } & \text { 2sgS-AUX-FV } & \text { INF-see-FV } & \text { COMP } & \text { 2S-2sgO-believe-FV }\end{array}$

'You will see the children believe you.'

As a complementizer, nga is used only with perception predicates wuur 'hear' and bon 'see', as well as with a single phasal predicate sigal 'continue, remain'. The semantics of the complementizer $n g a$ is not yet clear to us, but possible semantic motivations for the distribution will be discussed in Sections 5.2 on phasal predicates and 5.5 on perception predicates.

In addition to its use as a complementizer, as in (22), nga is frequently used as a temporal conjunction 'while, when', as in (23) (see also Nabirye 2016: 390-391 on the use of the cognate form in the closely related Soga with a similar range of functions).

$\begin{array}{llll}\text { nàsòmèré } & \text { ngà } & \text { ǹkyálì } & \text { mùtó } \\ \text { n-a-som-ere } & \text { nga } & \text { n-kya-li } & \text { mu-to } \\ \text { 1sgS-PST-study-PFV } & \text { CONJ } & \text { 1sgS-PERS-be } & \text { 1-young } \\ \text { 'I studied, when I was still young.' } & & \end{array}$

4.7 Other complementizers. In addition to $n t i, o b a$ and $n g a$, there are a few other less frequent complementizers, which need further study. One of them is $n i$, which is primarily used as the temporal ('when') and conditional ('if') conjunction. We have found examples of ni occurring with the verbs bon 'see' and izukir 'remember', as in (24) and (25).

\begin{tabular}{|c|c|c|c|}
\hline wábwóíné & $\downarrow_{\text {ní }}$ & búkwém๋ bá & lwáà bwé \\
\hline o-a-bwon-ire & {$[\mathrm{ni}$} & bu-ku-emb-a & lwa-abwe \\
\hline 2sgS-PST-watch-FV & COMP & 14S-PROG-sing-FV & AUG-language(11)11-2POSS \\
\hline 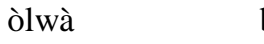 & bùnyàlá & & \\
\hline o-lwa & Bunyala] & & \\
\hline AUG-11.GEN & Bunyala(14) & & \\
\hline
\end{tabular}

$\begin{array}{lllll}\text { ìzúkí }{ }^{\prime} \text { rá } & \text { ní } & \text { twàìnùkìré } & \text { ókú } & \text { làngò èè }{ }^{\downarrow} \text { yó } \\ \text { izukir-a } & \text { [ni } & \text { tu-a-iruk-ir-ire } & \text { o-ku } & \text { Lango eyo] } \\ \text { remember-FV } & \text { COMP } & \text { 1pls-PST-run-APPL-PFV } & \text { AUG-17.LOC } & \text { Lango MED } \\ \text { 'Remember how [=when] we ran to that Lango.' } & \end{array}$

Another very infrequent and initially overlooked complementizer is the complementizer $m b u$ used exclusively with reported speech, as in (26). The complementizer $m b u$ occurs with statements only and never with questions or commands. On the basis of about two dozens available examples, it seems to have a speaker-evaluative meaning: the current speaker gives an evaluation about the discourse of another speaker (or much less frequently for self-quotation) ranging from uncertainty or hesitation to disbelief or doubt of the authenticity of the reported message. Similar constructions are discussed in Spronck (2012: 79) as "quotative-with-dubitative construction".

$\begin{array}{llllll}\text { Naye } & \text { abandi } & \text { ba-kob-a } & \text { mbu } & \text { oBunyala } & \text { bwaikanga } \\ \text { naye } & \text { a-ba-ndi } & \text { ba-kob-a } & {[\mathrm{mbu}} & \text { o-Bunyala } & \text { bu-a-ikang-a } \\ \text { but } & \text { AUG-2-other } & \text { 2S-say-FV } & \text { COMP } & \text { AUG-Bunyala(14) 14S-PST-reach-FV }\end{array}$

\footnotetext{
${ }^{7}$ The subject index of class 14 on the verb refers to 'children' and class 14 is used here in its diminutive function. The noun for 'children' otherwise belongs to class 2 and the agreement in this class appear on the possessive pronoun lwaabwe 'their'.
} 


$\begin{array}{lc}\text { oku } & \text { Nammanve. } \\ \text { o-ku } & \text { Nammanve } \\ \text { AUG-17.LOC } & \text { Nammanve(9) } \\ \text { 'But others say that the Bunyala reached Nammanve.' (written corpus) }\end{array}$

$M b u$ can also be used as a quotative particle without any complement-taking predicates to introduce reported speech with the respective speaker-evaluative meaning, as in (27) (see Section 2.4 on the connection between complementizers and quotatives, see also Section 4.4 on how $n t i$ is used as a quotative).

$\begin{array}{llll}\text { Abanyala } & \text { abasookere } & \text { balumire } & \text { mbu ensika } \\ \text { a-Banyala } & \text { a-ba-sook-ere } & \text { ba-lum-ire } & \text { mbu e-nsika } \\ \text { AUG-Banyala(2) } & \text { REL-2S-be.first-PFV } & \text { 2S-farm-PFV } & \text { QUOT } \\ \text { bazitwoire } & \text { Chope. } & \\ \text { ba-zi-two-ire } & \text { Chope } & \\ \text { 2S-10O-get-PFV } & \text { Chope(1) } & \\ \text { 'The first Banyala did farming and (it is said that allegedly) they got the hoes from } \\ \text { Chope.' (written corpus) }\end{array}$

A cognate complementizer $m b u$ with a similar distribution is reported for the closelyrelated Ganda. Murphy (1972: 332) defined it as a conjunction used "to introduce reported speech that, namely. It is similar in function to nti but implies doubt and uncertainty".

\section{Complement-taking predicates and complement semantics}

Below, we will discuss a number of complement-taking predicate classes and describe the distributional variation of complements within each class. The point of departure for the analysis of Ruuli were the classes of complement-taking predicates defined in Cristofaro (2003). However, it should be noted that we work with slightly different definitions of specifically modal, manipulative, perception, knowledge, and utterance predicates. We choose not to place complement-taking predicates occurring with several complement types in more than one category. Thus, Section 5.5 labeled perception predicates, for example, covers all constructions with complement-taking predicates that describe perception such as bon 'see' in constructions that describe 'direct perception' (I saw him leave), as well as constructions that describe 'indirect perception' (I saw that he left) In this way, we wish to display the versatility of individual complement-taking predicates, as well as systematically discuss the prevalence of contrasts between states-of-affairs and propositions in Ruuli complementation.

5.1 Modals. Modal predicates have meanings such as 'may' and 'can' and describe likelihood, possibility, ability, permission and obligation (Palmer 2001: 33). We follow Van der Auwera \& Plungian (1998) and distinguish two major types of modal expression, viz. possibility and necessity, as well as four modality domains, viz. participant-internal modality, participant-external modality with a subtype of deontic modality, as well as epistemic modality.

In Ruuli at least six different verbs are regularly used as modal predicates. Some of these verbs are attested in other West Nyanza languages with similar meanings (see e.g. Nabirye 2016: 313, Kawalya et al. 2018). Possibility is expressed in Ruuli by the modal verbs sobol and yinz ${ }^{8}$ both

\footnotetext{
${ }^{8}$ Kawalya et al. (2018) claim that the verb yinz is only attested in North Nyanza languages and is not found in Rutara, the branch of West Nyanza to which Ruuli belongs. However, Ruuli data, which were not available to the authors of that paper, contradict this claim.
} 
translated as 'can, may, be able'. These two verbs can express all possibility domains: participantinternal possibility, as in (28a) and (17b), non-deontic participant-external possibility, deontic participant-external possibility, as well as epistemic possibility, as in (28b).

$$
\text { a. }
$$

ǹsóbólá ókúsò ${ }^{+}$sóótóórà
n-sobola [o-ku-sosootoor-a
1sgS-can-FV AUG-INF-serve-FV
'I can serve a person a meal'

$$
\begin{array}{ll}
\text { òmúńtw } & \text { ékííbúlò } \\
\text { o-muntu } & \text { e-kiibulo] } \\
\text { AUG-person(1) } & \text { AUG-meal(7) }
\end{array}
$$

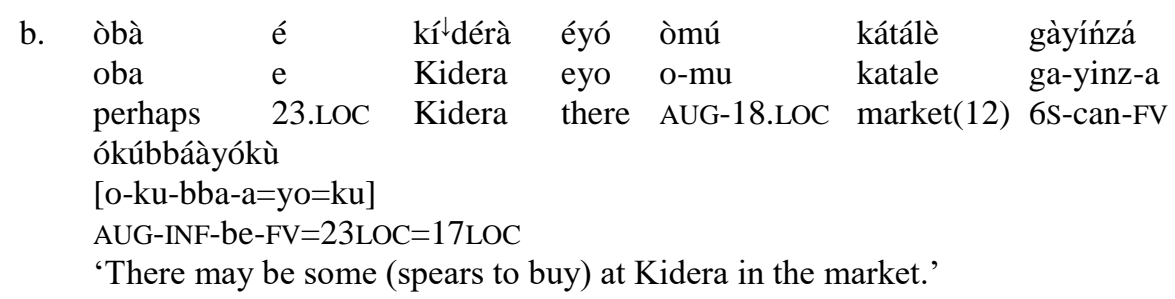

Necessity is expressed by the modal verbs lin and teek( $w)$ both translated as 'must, have to'. Both these verbs are used to express deontic (29a) and non-deontic participant-external necessity. Only teek $(w)$ is found in our corpus to express epistemic necessity, as in (29b).
a. òlìnà
$\begin{array}{ll}\text { kùsálá } & \text { mùsààyì } \\ \text { [ku-sal-a } & \text { musaayi] }\end{array}$
2sgS-have.to-FV INF-sacrifice-FV blood(3)
'You have to sacrifice blood.'
b. kàtééká
ka-teek-a
ókútbbáàmú
òmú
kídóńdóórò
12S-must-FV
[o-ku-bba-a=mu
o-mu
AUG-INF-be-FV=18.LOC AUG-18.LOC
kidondooro]
granary(7)
'It must be there in the granary.'

All the modal verbs discussed above occur exclusively with infinitive complements (introduced in Section 4.3).

To express participant-internal necessity the verb endy and occasionally tak are used. However, in most cases these two verbs are used with the meaning 'want' and in this meaning they take both infinitive and subjunctive complements primarily conditioned by whether the subject of the matrix clause and the complement verb are identical (see Section 5.4). In their modal meaning, they primarily also allow for these two complementation strategies under the same conditions.

With the same subject in the two clauses we find an infinitive complement, as in (30a), whereas with different subjects the subjunctive is used, as in (30b). In addition to these two verbs, the corpus contains a few tokens of the verb etaag 'need', which is also used to express participantinternal necessity. Cognates of this verb are found in a number of closely related languages (see e.g. Nabirye 2016:313, Kawalya et al. 2018).

$$
\begin{array}{lll}
\text { a. } & \text { ǹkwèndyá } & \text { kútà }{ }^{\text {nákà }} \\
\text { n-ku-endy-a } & \text { [ku-tanak-a] } \\
\text { 1sgs-PROG-need-FV } & \text { INF-vomit-FV } \\
\text { 'I need to vomit.' } &
\end{array}
$$

\footnotetext{
Though the possibility of a borrowing from the dominant Ganda cannot be excluded, the verb yinz is frequently used in the corpus and occurs in a wide array of contexts building an integral part of Ruuli grammar.
} 


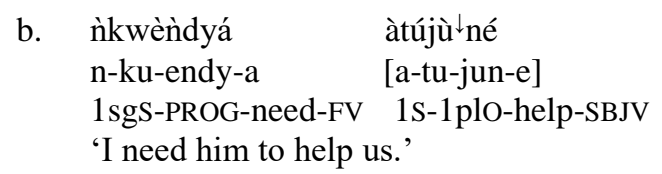

Of the verbs discussed above, only some are also found as lexical verbs taking nominal objects. Sobol has the meaning 'manage smth./smb.' when used as the main verb, eetag is used as 'need smth.', lin is common as 'have smth./smb.', tak and endy both meaning 'want smth./smb.',

5.2 Phasals. Phasal predicates are predicates that describe the beginning, continuation or end of an event. There are at least five phasal predicates in Ruuli: tandik 'start/begin', mal 'finish', lek 'stop/leave', onger 'continue' and sigal 'remain, continue'.

Phasal predicates are primarily used with infinitives, as in (31).

a. bàtáńdíkíré ókùtù búlyábúlyà

$\begin{array}{ll}\text { ba-tandik-ire } & \text { [o-ku-tu-bulyabuly-a] } \\ \text { 2S-start-PFV } & \text { AUG-INF-1plO-confuse-FV }\end{array}$

'They started confusing us.'

$\begin{array}{llll}\text { b. nì } & \text { ǹtáńdíká } & \text { ò kúbínà } \\ \text { ni } & \text { n-tandik-a } & \text { [o-ku-bin-a] } \\ \text { when } & \text { 1sgS-start-FV } & \text { AUG-INF-dance-FV } \\ \text { 'When I start dancing, ...' } & \end{array}$

In contrast to other phasal predicates sigal 'remain, continue' prefers a different construction, namely a complement marked by the complementizer nga presented in Section 4.6, as in (32). The complementizer $n g a$ is otherwise only found with perception predicates (cf. Section $5.5)$.

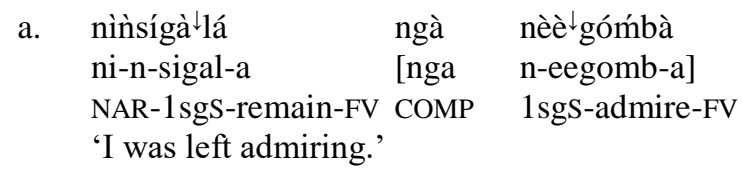

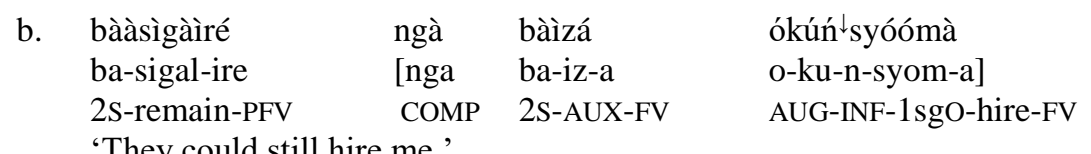

'They could still hire me.'

5.3 Manipulatives. Manipulative predicates are predicates with meanings such as 'make' and 'force'. They describe the coercion of a participant into carrying out an action. Ruuli appears to lack specialized manipulative predicates like English force or prevent. Functions of constructions with these kinds of complement-taking predicates are primarily carried out by the morphological causative constructions, i.e. by using verbs with the dedicated causative suffix, as in (15) and (41a). The best candidate for a manipulative predicate in Ruuli is yamb 'help', as in (33), which occurs with infinitive complements. Note also that it is possible to use utterance predicates in a manipulative sense as described in Section 5.9.
tú`báyáḿbá
ókúlìmá
èmwàànì
tu-ba-yamb-a
[o-ku-lim-a
e-mwani]
1pls-2O-help-FV
AUG-INF-cultivate-FV
AUG-coffee(10)
'We help them to cultivate coffee plantations.' 
5.4 Desideratives. Desiderative predicates are predicates with meanings like 'want' and 'wish'. Ruuli frequently employs two desiderative predicates, viz. tak 'want, desire' and endy 'want, like'. These predicates tak 'want, desire' and endy 'want, like' most often introduce infinitive complements, as in (34a), but subjunctive complements, as in (34b), are also frequent. The two predicates are also used to express participant-internal necessity and in these function they were discussed and exemplified in Section 5.1.
a. tútkútáká
kúkìłyíńdúlà
tu-ku-tak-a
[ku-ki-yindul-a]
1plS-PROG-want-FV INF-7O-change-FV
'We want to change it.'
b. tú ${ }^{k}$ kútáká mù ${ }^{\dagger}$ tééwò érésò ${ }^{\natural}$ ní
tu-ku-tak-a [mu-ta-e=wo e-lesoni]
1pls-PROG-want-FV 2pls-introduce-SBJV=LOC AUG-lesson(9)
'We want you to introduce a lesson.'

According to Haspelmath (1999: 41-42) there is a cross-linguistic tendency for samesubject and different-subject constructions with so-called 'want' complements to take morphosyntactically asymmetric complements. Among others, Swahili (Bantu) is given as an example of a language, where infinitives are used in same-subject constructions, while subjunctives are used in different-subject constructions. Also in Ruuli we find a correlation between same vs. different subject and the type of complement: Most of the different-subject constructions found with tak 'want, desire' and endy 'want, like' are subjunctive, whereas same-subject constructions with these verbs tend to have infinitive complements. However, there is still a non-negligible amount of examples of different-subject constructions involving infinitives, as well as same-subject constructions involving subjunctives. Possible motivating factors for the distribution of infinitives and subjunctives are discussed further in Section 6.1 below.

5.5 Perception predicates. Perception predicates are predicates describing a physical sensation, such as 'see', 'hear' and 'feel'. Ruuli has at least two perception predicates, viz. bon 'see' and wuur 'hear'. They can occur with complements that express states-of-affairs and signify 'direct perception' (also called 'immediate perception'), as well as complements expressing propositions that signify information acquired via perception (known as 'indirect perception' or 'knowledge acquired') (Dik \& Hengeveld 1991, Boye 2010). Indicative complements, as in (35), - with or without complementizer $n t i$ - are most common. The complementizer $n t i$ can only be used to indicate an 'indirect perception' reading.

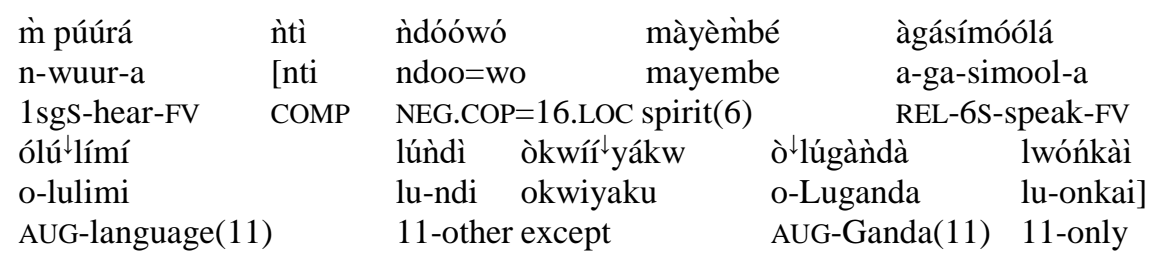

'I hear that there are no spirits that speak any other language except Ganda.'

In contrast to other predicate types, perception predicates often take complements with $n g a$, but it is not yet clear whether there is a morphosyntactic or semantic explanation for the distribution of nga. With wuur 'hear' it seems that the presence and absence of $n g a$ contrasts direct and indirect perception, as in (36a) and (36b), respectively. Example (36a) describes the perception 
of the sound of the wind, whereas example (36b) describes knowledge acquired through hearsay rather than the perception of sound.
a. ̀̀púúrá
éḿpéwò

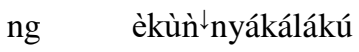
n-wuur-a
[e-mpewo
nga
e-ku-n-yakal-a=ku]
1sgs-hear-FV AUG-wind(9)
COMP 9S-PROG-1sgO-pass-FV=17LOC
'I heard/felt wind passing over me.'
b. ìnúúrá
àzwààmú
ólúbááwò
n-wuur-a
[a-zwamu
a-lubaawo]
1sgs-hear-FV
1S-produce
AUG-timber(11)
'I hear it (a specfic type of tree) produces timber.'

However, with bon 'see' we find complements that express indirect perception marked by $n g a$, as in (37a), parallel to examples without a complementizer, as in (37b).
a. ǹkùkìróléérà
nkükìroleeerà
n-ku-ki-lool-er-a
1sgs-PROG-7O-see-APPL-FV
è ‘kízíbù.
$\begin{array}{ll}\text { ngà } & \text { kìyínzá } \\ \text { [nga } & \text { ki-yinz-a } \\ \text { COMP } & 7 \mathrm{~S}-\text { may-FV }\end{array}$
ókúbbá
e-ki-zibu]
AUG-7-difficult
'I am seeing (observing) that it may be difficult.'

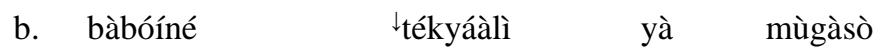
ba-boine [ti-e-kya-li ya mugaso]
2pls-see.PFV NEG-9S-PERS-be 9.GEN importance(3)
'They have seen they are no longer of importance.'

It is clear that perception predicates differ from other predicate classes due to their relatively frequent co-occurrence with the complementizer $n g a$, which is otherwise only found with the phasal predicate sigal 'remain/continue'. The contrast between direct and indirect perception seems to play a role in constructions with wuur 'hear', but not so much with bon 'see'. At present, it is not yet clear whether a comprehensive semantic analysis of $n g a$ is really tenable or whether the synchronic distribution of $n g a$ is simply what is left of a previously more widespread use.

5.6 Knowledge predicates. Knowledge predicates are predicates with meanings such as 'know', 'learn' and 'teach' that signify the state, acquisition or transfer of knowledge. Predicates describing knowledge of information (epistemic knowledge) or 'know how' (action knowledge) are included in this class. There are at least ten complement-taking knowledge predicates in Ruuli, they include many 'know', izukir 'remember', ebeer 'forget', ebw 'forget', etej 'understand', tegeer 'realize, understand', egesy 'teach', tendek 'train', somesy 'teach', and lang 'show'.

As a group, knowledge-predicates most often take indicative complements with or without $n t i$ as in (38) and (39), in which case they describe epistemic knowledge.

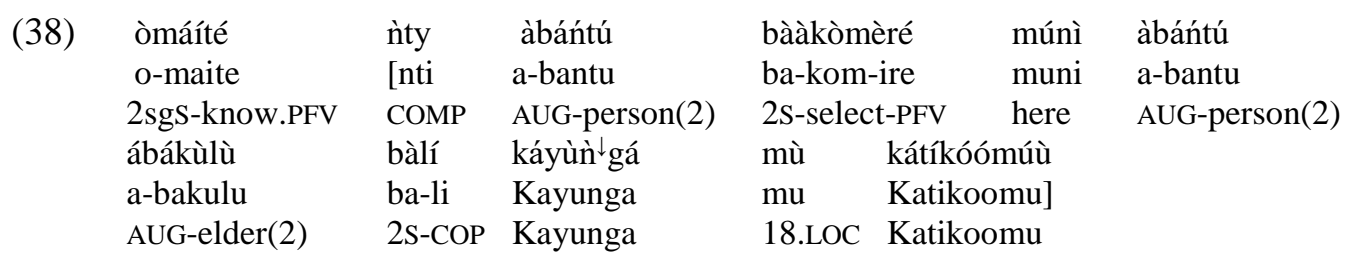

'Do you know that people have selected elders and they are in Kayunga at Katikoomu?' 


$\begin{array}{llllll}\text { náyé } & \downarrow \text { '́zúkìrà } & \text { ǹty } & \text { òmwáànà } & \text { yààlì } & \downarrow \text { mwóójò } \\ \text { naye } & \text { izukir-a } & \text { [nti } & \text { o-mwana } & \text { a-a-li } & \text { mwojo] } \\ \text { but } & \text { remember-FV } & \text { COMP } & \text { AUG-child(1) } & \text { 1S-PST-be } & \text { boy(1) } \\ \text { 'But remember that the child was a boy.' } & & \end{array}$

As for the complementizer $n t i$, we find an equal number of complements with and without $n t i$ with complements of many 'know' and it thus appears that it is completely optional. On the other hand, izukir 'remember' is more frequently used without the complementizer nti. Finally, complements of lang 'show' are always marked by $n t i$, as in (40).

\begin{tabular}{|c|c|c|c|c|}
\hline ngà & bá`túláńgá & ǹty & è & ${ }^{\downarrow}$ kyámúgánwà \\
\hline nga & ba-tu-lang-a & {$[\mathrm{nti}$} & $\mathrm{e}$ & Kyamuganwa \\
\hline CONJ & 2pls-1.plo-show-FV & COMP & 23.LOC & Kyamuganwa \\
\hline \multicolumn{2}{|c|}{ wàbbààǹ ${ }^{\downarrow}$ gáwò } & éńjázì & & \\
\hline \multirow{2}{*}{\multicolumn{2}{|c|}{$\begin{array}{l}\text { wa-bba-ang-a=wo } \\
10 \text { - }\end{array}$}} & enjazi] & & \\
\hline & & well(10 & & \\
\hline
\end{tabular}

'And they showed to us that there were wells at Kyamuganwa.'

Infinitives, though infrequent with knowledge predicates, are used when the complementtaking predicate means 'know how to', as in (41a), 'teach how to', as in (41b) and (41c), and 'forget to', as in (41d). Note that the same complement-taking predicate many 'know'is used in (38) and (41a). It can be seen how the choice of complement type (indicative vs. infinitive) makes a difference to the meaning of the complement construction (epistemic knowledge vs. know how).

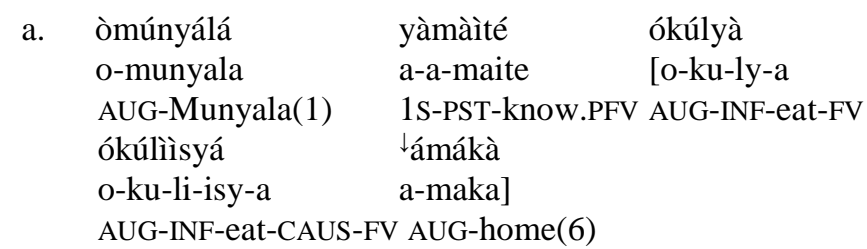

'A Munyala knew how to eat, how to feed the home.'

b. ómwáàlà

o-muwala

AUG-girl(1)

'We teach the g

$$
\begin{array}{ll}
\text { túmwéégè } \downarrow_{\text {syá }} & \text { ókúlàmùcà } \\
\text { tu-mu-egesy-a } & \text { [o-ku-lamuc-a] } \\
\text { 1pls-1sgO-teach-FV } & \text { AUG-INF-greet-FV }
\end{array}
$$
c. bàkúsómésyé ábáńtù òkúyìǹ ${ }^{d u ́ l a ́ ~}$
ba-ku-somesy-e a-bantu [o-ku-yindul-a
2S-PROG-teach-SBJV AUG-person(2) AUG-INF-translate-FV
èdíkìsònà ${ }^{2}$ bágíté òmú lúlímì
e-dikisonare ba-gi-t-e o-mu lulimi
AUG-dictionary(9) 2S-9O-put-SBJV AUG-18.LOC language(11)
lwàiswé ólúnyálà
lu-aiswe o-Lunyala]
11-1plposs AUG-Lunyala(11)

'They may teach people how to translate a dictionary into Lunyala, our language.'

d. nì twèrábírá

ni tu-erabir-a

CONJ 1pls-forget-FV

òkúsùm $\downarrow$ bísyà

o-ku-sumb-isy-a

'And we forget how to cook food.'

AUG-INF-cook-CAUS-FV 
Knowledge predicates occasionally occur with the complementizer oba 'whether' discussed and illustrated in Section 4.5. This complementizer marks indicative complements and expresses doubt towards the proposition.

5.7 Propositional attitude predicates. Propositional attitude-predicates are predicates with meanings like 'think' and 'believe'. There are at least two propositional attitude predicates in Ruuli: lowooz 'think', illustrated in (42), and ikiriz 'accept, agree to, allow, believe, permit', illustrated in (43). Propositional attitude predicates most often occur with indicative complements with or without $n t i$, as in (42a) and (42b).
a. ǹdówóózá
$\downarrow$ bákúfúnámù
kìdóòlì
1sgS-think-FV
[ba-ku-fun-a=mu
ki-dooli]
'I think they benefit little.'
7-little
b. ǹkúlówóózá ǹtì túkútàndíkáwò
n-ku-lowooz-a [nti tu-ku-tandik-a=wo
1sgS-PROG-think-FV COMP 1pls-PROG-start-FV=16.LOC
'I was thinking that we start up projects.'

épúlòyèkìtì

e-puloyekiti]
ǹkwì̀kírízá
ǹtì
wàbbáàwòkw
n-ku-ikiriz-a
[nti
wa-bba- $\mathrm{a}=\mathrm{wo}=\mathrm{ku}$
1sgS-PROG-believe-FV
'I believe that there will be a stone.'

$\begin{array}{lll}\text { àlówóózá } & \text { ókwáàbà } & \text { n'-òmwîbbì } \\ \text { a-lowooz-a } & \text { [o-ku-aba } & \text { na-o-mwibbi] } \\ \text { 1S-think-fv } & \text { AUG-INF-go } & \text { COM-AUG-thief(1) }\end{array}$

\'́bbáàlè

COMP 16 sgS-COP-FV=16.LOC=17.LOC

e-ibbaale]

AUG-stone(5)

Both lowooz and ikiriz also occur with infinitive complements. The infinitive is possible with lowooz 'think' when the complement expresses something that is planned to happen, as in (44).

'He thinks (i.e. intends) to go with the thief.'

Thus, the complement-taking predicate in (44) does not actually express an 'attitude' towards a proposition as the name of the class would suggest. It means 'intend' rather than 'think'. However, we chose to keep the class name to mirror the ones used in Cristofaro (2003).

The infinitive is very common with ikiriz and then ikiriz has the meaning of 'allow, to permit', as in (45).
éłkúrúháànì
èikírízá
ókú ${ }^{\downarrow}$ gúlá
ómúkàzì
e-Kuruhani
e-ikiriz-a
[o-ku-gul-a
o-mukazi]
AUG-Koran(9) 9S-accept-FV
AUG-INF-buy-FV
AUG-woman(1)
'The Koran accepts (i.e. permits) buying a woman.'

5.8 Emotive predicates. Emotive predicates are predicates describing an emotion with meanings such as 'hate', 'love' etc. There are at least four emotive predicates in Ruuli: tiin 'fear, to be afraid' (46), sanyuk 'be happy, to be glad' (47), semeerw 'be happy, to be glad' (48), and eyanz 'thank, to be grateful' (49). Emotive predicates always occur with infinitives. 
(46)

$\begin{array}{llllll}\text { ǹjè } & \text { ǹtííná } & \text { ókú }{ }^{\prime} \text { ńnyákályá } & \text { òmù } & { }^{\downarrow} \text { kánwá } & \text { káǹgè } \\ \text { nje } & \text { n-tiin-a } & \text { [o-ku-nyakaly-a } & \text { o-mu } & \text { kanwa } & \text { ka-nge] } \\ 1 \text { sg } & \text { 1sgs-be.afraid-FV } & \text { AUG-INF-pass-FV } & \text { AUG-18LOC mouth(12) } & \text { 12-1sg.POSS } \\ \text { 'As for me, I fear to pass it through my mouth.' } & \end{array}$

$\begin{array}{llll}\text { òkyótó } & \text { nàsá }{ }^{n y u ́ k a ́} & \text { ókúfùná } & \text { àbáànà } \\ \text { o-Kyoto } & \text { ni-a-sanyuk-a } & \text { [o-ku-fun-a } & \text { a-baana] } \\ \text { AUG-Kyooto(1) } & \text { NAR-1s-be.happy-FV } & \text { AUG-INF-get-FV } & \text { AUG-child(2) }\end{array}$

(48)

'Kyoto was happy to get children.'

$\begin{array}{llll}\text { ǹjééná } & \text { nsèmè } \downarrow \text { réírwé } & \text { ókú }{ }^{b b a ́} & \text { ànì } \\ \text { nje-ena } & \text { n-semereirwe } & \text { [o-ku-bba } & \text { ani] } \\ \text { 1sg-ADD.FOC } & \text { 1sgs-be.happy.PFV } & \text { AUG-INF-COP } & \text { here }\end{array}$

$\begin{array}{lll}\text { nèyáńzíré } & \text { mùnó } & \text { òkúkù } \downarrow \text { sáńgà } \\ \text { n-eyanz-ire } & \text { muno } & \text { [o-ku-ku-sang-a] } \\ \text { 1sgS-appreciate-PFV } & \text { much } & \text { AUG-INF-2sgO-meet-FV } \\ \text { 'I am pleased to meet you.' } & \end{array}$

5.9 Utterance predicates. Utterance predicates have meanings such as 'say', 'ask' and 'tell' and signify information transfer, information requests or orders and directions delivered by means of speech. There is more than a dozen utterance predicates in Ruuli, the most common are kob 'to say, to tell', buuly 'ask (a question)', sab 'ask (for), request, pray (for)' and gaan 'refuse, reject'.

In principle, it is possible to distinguish between direct and indirect reported speech in Ruuli, although many tokens in the corpus are ambiguous due to ambiguous reference of deictic elements. The most reliable criteria are shifts in pronominal reference, as in (50a) vs. (50b), as well as the use of imperatives. Temporal deixis is less reliable. Further investigations are needed to assess the reliability of spatial deixis and of other discourse features in distinguishing between the two types of reported discourse (for a discussion of criteria for the distinction between direct and indirect discourse see e.g. Güldemann 2008: 27-28). Direct speech is especially frequent with kob 'say, tell' and buuly 'ask (a question)'.

Utterance predicates are the most versatile of all complement-taking predicates in Ruuli. For instance, the most common utterance predicate by far, kob 'say, tell', occurs with direct and indirect reports of assertions, questions and commands. Structurally, it can occur with indicatives, subjunctives and infinitives. In what follows we provide examples of direct and indirect reports of assertions, direct and indirect reports of questions, as well as of direct and indirect reports of commands introduced by utterance predicates.

Reported assertions are often introduced by $n t i$, but the presence or absence of $n t i$ is not indicative of the complement being a direct or indirect report, cf. (50a) and (50b). Direct speech complements are marked by $n t i$ slightly more often than indirect speech complements.

a. Direct report of assertion

$\begin{array}{llllll}\text { àkùkóbá } & \text { ǹjé } & \text { ǹdí } & \text { músájjá } & \text { wá } & \text { kábákà } \\ \text { a-ku-kob-a } & \text { [nje } & \text { n-li } & \text { musajja } & \text { wa } & \text { kabaka] } \\ \text { 1s-2sgO-tell-FV } & 1 \text { sg } & 1 \text { sgs-be } & \text { man(1) } & \text { 1.GEN } & \text { king(1) }\end{array}$

'He tells you, "I am the king's man".'

b. Indirect report of assertion

$\begin{array}{lllll}\text { yàsààréwó } & \downarrow_{\text {kúkóbá }} & \text { ǹtì } & \text { ákìry } & \text { ázwééwò } \\ \text { a-a-saarewo } & \text { ku-kob-a } & {[\text { nti }} & \text { akiri } & \text { a-Zw-e=wo } \\ \text { 1S-PST-decide.PVF } & \text { INF-say-FV } & \text { COMP } & \text { at.least } & \text { 1S-leave-SBJV=16LOC }\end{array}$




\begin{tabular}{|c|c|c|}
\hline ómú & má ${ }^{\prime}$ á & \áyábè \\
\hline o-mu & maka & a-ab-e] \\
\hline AUG 18.LOC & home(6) & $1 \mathrm{~s}-\mathrm{go}-\mathrm{SBJV}$ \\
\hline
\end{tabular}

Indicative complements of utterance predicates marked by $n t i$ do not have any special characteristics in comparison to indicative complements of other complement-taking predicates that co-occur with $n t i$ (perception, knowledge and propositional attitude predicates).

Direct reports of polar questions (yes/no-questions) do not have any special characteristics distinguishing them from reported assertions. This follows naturally from the fact that independent clause polar questions are morphosyntactically identical to independent clause assertions in Ruuli. Direct reports of questions can be marked by $n t i$ as in (51).

\begin{tabular}{lllll}
\multicolumn{2}{l}{$\begin{array}{l}\text { Direct report of question } \\
\text { nàmbúùlyà }\end{array} \quad$ ǹtì } & mwààná & wángè & òyàbìrèkù \\
ni-a-n-buuly-a & [nti & mwana & wa-ange & o-ab-ire=ku \\
NAR-1S-1sgO-ask-FV COMP & child(1) & 1-1sgPOSS & 2sgS-go-PFV=17.LOC \\
òmú & ńkwíi & & \\
O-mu & nkwi] & & \\
AUG-18.LOC & firewood(10) & &
\end{tabular}

'She asked me, "My child have you ever gone to collect firewood?"'

Indirect reports of questions, as in (52) are introduced by $o b a$. In such cases $o b a$, which is otherwise used as a conjunction 'or' in Ruuli, functions as a complementizer somewhat similar in meaning to English whether (cf. Section 4.5). The occurrence of a morpheme functioning both as a conjunction 'or' and as a complementizer used to report polar questions is not surprising: Meanings such as 'or' are related to uncertainty and uncertainty is related to polar questions (cf.

Boye 2012).

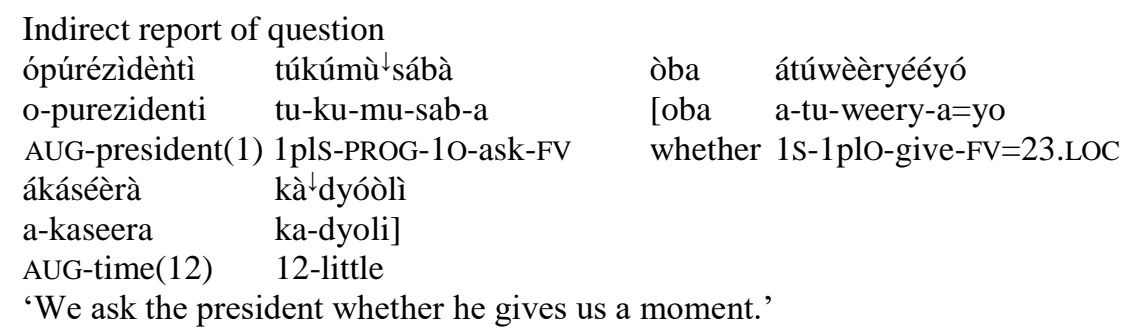

'We ask the president whether he gives us a moment.'

In direct reports of commands and requests the imperative form of the verb (stem and final vowel, no subject indexing) is used, exactly as in the imperative main clause.

(53) Direct report of command/request

$\begin{array}{lll}\text { nànòkóbá } & \text { séé }{ }^{\text {nyá }} & \text { éńkwì } \\ \text { ni-a-n-kob-a } & \text { [seeny-a } & \text { e-nkwi] } \\ \text { NAR-1S-1sgS-say-FV } & \text { collect-FV } & \text { AUG-firewood(10) } \\ \text { 'She said, "Collect firewood!"” } & \end{array}$

Indirect reports of commands are achieved by employing a subjunctive verb form as in (54) or - less frequently - by an infinitive. 
(54)
Indirect report of command/request
nàyé twààmùkòbèré
naye tu-a-mu-kob-ire
àtúwèèryééyo
ómusááyì
but 1pls-PST-10-say-PFV
[a-tu-weery-e=yo
o-musaayi]
'But we told him to give us some blood.'

Utterance predicates also occur with the infrequent complementizer $m b u$ presented in Section 4.7. Further research is needed to describe its distribution in more detail.

5.10 Other complement-taking predicates. In this final section we provide some examples of less frequent complementtaking predicates yombok 'struggle' and the inherently reflexive ebaly 'thank'. These predicates occur with infinitive complements.

$\begin{array}{lll}\text { túkú }{ }^{\downarrow} \text { gádà } & \text { ò`kwómbòká } & \text { òlùbìrì } \\ \text { tu-ku-gad-a } & \text { [o-ku-yombok-a } & \text { o-lubiri] } \\ \text { 1plS-PROG-struggle-FV } & \text { AUG-INF-build-FV } & \text { AUG-palace(11) } \\ \text { 'We are struggling to build a palace.' } & \end{array}$
wéébállé
kúbyáálà
o-ebaly-e
[ku-byal-a]
2sgS-thank-SBJV
INF-give.birth-FV
'Thank you for giving birth.'

\section{Discussion}

In the previous sections we have pointed out two main predictors of complement choice with different predicate classes: 1) different-subject and same-subject constructions and 2) the semantic distinction between states-of-affairs and propositions. This section summarizes the most important analytic points and discusses the predictions further.

6.1 Comparison of the subjunctive and the infinitive: different-subject vs. same-subject constructions. As described in Section 4 subjunctive complements follow a limited number of predicates, namely modals, phasals, desideratives, and utterance predicates, but infinitives combine with all predicate classes except for perception predicates. Some complement-taking predicates in Ruuli thus allow both infinitive and subjunctive complements.

Several other Bantu languages have complement-taking predicates that can introduce both subjunctive and infinitive complements, but the motivation for choosing one over the other is likely language-specific. For Bemba (East Bantu, M42; Zambia), for example, Givón (1969: 224) has noted that the meaning difference between subjunctive and infinitive complements of manipulative predicates is that with subjunctives the event in the complement may or may not have happened, whereas with infinitives it has happened (at some point). In Nzadi (Narrow Bantu, B30; DR Congo) infinitives are generally used in samesubject constructions, while subjunctives are used in differentsubject constructions (Crane et al. 2011: 180-182). Such an analysis does not comprehensively account for the distribution of infinitives and subjunctives in Ruuli. Realis status does not seem to be a motivating factor at all, and while the account in terms of the distinction between differentsubject and same-subject constructions does indeed motivate the distribution to some degree, it cannot stand on its own. Complements in different-subject constructions with desiderative predicates, for example, are almost always subjunctive, but same-subject complements are not always infinitives, as shown in (57a). 
a. àkwèǹdyá

a-ku-endy-a

1S-PROG-want-FV

áyábé

[a-ab-e

1S-go-SBJV

'She wants to go to university.'

b. ǹjè

nje

ǹkwèǹdyá

n-ku-endy-a

1sgS-PROG-want-FV

'For me, I want to study catering.' òkú

o-ku

AUG-17.LOC

¿yúnívásítè

university]

university(9)

It is not yet entirely clear what motivates the use of a subjunctive instead of an infinitive in same-subject constructions, but one possibility is that the choice is motivated by a rather subtle semantic difference: when endy introduces an infinitive complement as in (57b) it resembles English 'want', whereas when endy introduces subjunctive complements the meaning of endy is more akin to 'would like to', as in (57a).

6.2 States-of-affairs and propositions. In Section 2 above we discussed the connection between semantic contrasts and morphosyntactic contrasts in complementation, in particular the contrasts between states-of-affairs and propositions as found in complement constructions with perception predicates (direct perception vs. indirect perception), knowledge predicates (epistemic knowledge vs. action knowledge/know how) and utterance predicates (reports of assertions or questions vs. reports of commands/requests). In this section we relate the contrast between state-of-affairs and propositions to Ruuli complementation.

Several tests for identifying whether a complement clause expresses a state-of-affairs or a proposition have been proposed in the literature. Among them are the distribution of complements on specific predicate types and the acceptability of epistemic modification of the complement (e.g. insertion of maybe in English) (for discussions of appropriate tests cf. Boye 2012, Serdobolskaya 2016). We will focus on the distribution of complement types and complementizers over predicate classes.

In Ruuli the contrast between propositions and states-of-affairs is found within different complement-taking predicate classes, namely knowledge-predicates, propositional attitude predicates, utterance-predicates and perception-predicates.

For example, (58a) and (58b) illustrate the contrast between propositional and state-ofaffairs complements in Ruuli knowledge-predicate complementation. The indicative complement of many 'know' in (58a) represents epistemic knowledge, whereas the infinitive complement of many 'know' in (58b) designates 'know how'. (Note that the infinitive construction does not have any element corresponding to English how).

a. Proposition (epistemic knowledge)

$\begin{array}{llll}\text { òmáitè } & \text { yééná } & \text { àyéńdyá } & \text { ókwáàyà } \\ \text { o-maite } & \text { [ye-ena } & \text { a-endy-a } & \text { o-ku-yizukiry-a] } \\ \text { 2sgS-know.PFV } & \text { 1-ADD.FOC } & \text { 1S-need-FV } & \text { AUG-INF-be.reminded-FV }\end{array}$

'You know he also needs to be reminded.'

b. State-of-affairs (action knowledge/know how)

$\begin{array}{ll}\text { àmáíté } & \text { ókútsáányà } \\ \text { a-maite } & \text { [o-ku-sany-a] } \\ 1 \text { 1s-know.PFV } & \text { AUG-INF-swim-FV } \\ \text { 'He knew how to swim.' }\end{array}$

A parallel contrasts from utterance-predicate complementation is given in example (59). In this case too, a morphosyntactic contrast is accompanied by a semantic contrast. Example (59a) 
illustrates an indicative complement (marked by the complementizer nti) contrasting with a stateof-affairs complements (a subjunctive in (59b)

a. Proposition (report of assertion)

\begin{tabular}{|c|c|c|c|c|}
\hline ábágáǹdà & nìbàkóbá & ǹtì & bámáfúḿbè & níbó \\
\hline a-Baganda & ni-ba-kob-a & [nti & bamafumbe & ni-bo \\
\hline AUG-Baganda(2) & NAR-2S-say-FV & COMP & African.civet.clan(2) & COP-2 \\
\hline bàbyáàlá & ò káwúmúpúlì & & & \\
\hline ba-byal-a & o-Kawumpuli] & & & \\
\hline 2s-produce-FV & AUG-Kawumpu & & & \\
\hline
\end{tabular}

b. State-of-affairs (report of command/request)

$\begin{array}{lll}\text { nìbàkóbá } & \text { ákírì } & \text { tùbyáàlè } \\ \text { ni-ba-kob-a } & \text { [akiri } & \text { tu-byal-e] } \\ \text { NAR-2s-say-FV } & \text { at.least } & \text { 1pls-give.birth-SBJV }\end{array}$

'They said, (that) we should at least produce.'

The morphosyntactic and semantic contrasts in examples (58), (59) as well as those found with propositional attitude predicates (propositional attitude vs. intention) and perception predicates (direct vs. indirect perception) (see sections 5.7 and 5.5) are comparable to e.g. English contrasts such as She knows that he plays the piano vs. She knows how to play the piano (see Section 2.5). As discussed in Section 5.5, the picture is somewhat less clear for perception-predicate complementation, a predicate class that has otherwise received much attention in studies of contrasts between states-of-affairs and propositions (specifically direct and indirect perception) in relation to other languages (Dik \& Hengeveld 1991, Schüle 2000, Boye 2010)

Indicative complements and the complementizers nti and oba occur in constructions where the complement is arguably propositional (for an example with oba see Section 5.9). When the complement is indicative the complement-taking predicate functions as the kind of predicates that have been related to propositions, e.g. epistemic knowledge predicates, propositional attitude predicates and assertive utterance predicates (Cristofaro 2003, 2013, Noonan 2007, Boye 2012, Sørensen 2013, Sørensen \& Boye 2015). Infinitives and subjunctives on the other hand generally express states-of-affairs. Non-epistemic modals as well as phasals, desideratives and directive utterance-predicates, which have been related to state-of-affairs (Cristofaro 2003, Noonan 2007, Boye 2012), occur with infinitives and/or subjunctives and do not occur with complementizers.

On the basis of the available data, the contrast between states-of-affairs and propositions can be said to be expressed quite systematically in Ruuli. Infinitive and subjunctive complements express states-of-affairs in contrast to indicative complements which express propositions. Thus, no one complement type appears to be completely polyfunctional between the two readings as is the case in some languages (Boye 2010: 407) - with the exception that epistemic modals can take infinitives expressing a proposition (but note that epistemic modals are not included in the class of modals in Cristofaro 2003, Noonan 2007). But there is tendency for complement-taking predicates to be polyfunctional and take more than one type of complement.

\section{Conclusion and outlook}

We have made a first attempt at a description of the morphosyntax and semantics of clausal complementation in Ruuli. We have identified and characterized the main complement-taking predicates and complement types and discussed the distribution of complements and complementizers. We have also discussed semantic features motivating complement structures, in particular the contrast between states-of-affairs and propositions. 
Ruuli has a wide range of complement-taking predicates spanning most of the semantic classes identified cross-linguistically (Givón 2001, Cristofaro 2003, Dixon 2006, Noonan 2007). As in many other Bantu languages the main complement types are indicatives, subjunctives and infinitives, marked by final vowel $-a$, final vowel $-e$ and class marker $(o) k u-$, respectively. We found that the infinitive affix has the form $k u$ when the complement-taking predicate is negated and that there is free variation between $o k u$ and $k u$ when the complement-taking predicate is not negated.

The most frequent complementizer is $n t i$, which optionally introduces indicative complements, followed by $n g a$, which typically follows perception predicates, and $o b a$ which indicates doubt towards the proposition in the complement.

We have shown that many types of complement-taking predicates systematically take morphosyntactically different complement types according to whether the complement expresses a proposition or a state-of-affairs. Classes of complement-taking predicates which have been associated with state-of-affairs complements cross-linguistically, like modals and phasals, take infinitive complements in Ruuli, while other predicate classes like knowledge predicates and utterance predicates take both indicative and infinitive complements with an associated semantic contrast between propositions and state-of-affairs. Indicative complements are generally used to express propositions while subjunctive and infinitive complements express state-of-affairs (except perhaps for perception-predicate complementation). The distribution of complement types relative to predicate types thus appears to be semantically motivated by the contrast between states-of-affairs and propositions and thus adds evidence to already observed cross-linguistic trends.

Similar complement contrasts, such as contrasts between indicatives and infinitives used to describe epistemic knowledge and 'know how', respectively, are found in existing descriptions of Bantu languages. However, future studies might benefit from systematically looking for possible contrasts with all predicate classes although they might be rare.

\section{References}

Ashton, Ethel O., Enoch M. K. Mulira, E. G. M. Ndawula \& Archibald Norman Tucker. 1954. A Luganda grammar. Longmans, Green \& Company.

Boye, Kasper. 2010. Reference and clausal perception-verb complements. Linguistics 48(2). 391-430.

Boye, Kasper. 2012. Epistemic meaning: A crosslinguistic and functional-cognitive study. Berlin: De Gruyter Mouton.

Boye, Kasper \& Peter Harder. 2007. Complement-taking predicates: Usage and linguistic structure. Studies in Language 31(3). 569-606.

Crane, Thera Marie, Larry M. Hyman \& Simon Nsielanga Tukumu. 2011. A grammar of Nzadi. Berkeley: University of California Press.

Cristofaro, Sonia. 2003. Subordination. Oxford: Oxford University Press.

Cristofaro, Sonia. 2013. Utterance complement clauses. In Dryer, Matthew S. \& Haspelmath, Martin (eds.), The World Atlas of Language Structures Online. Max Planck Institute for Evolutionary Anthropology. (22 August, 2018).

Dik, Simon C. \& Kees Hengeveld. 1991. The hierarchichal structure of the clause and the typology of perception-verb complements. Linguistics 29(2). 231-259.

Dixon, R. M. W. 2006. Complement clauses and complementation strategies in typological perspective: A cross-linguistic typology. In R. M. W. Dixon \& Alexandra Y. Aikhenvald (eds.), Complementation, 1-48. Oxford: Oxford University Press.

Frajzyngier, Zygmunt. 1995. A functional theory of complementizers. In Joan Bybee \& Suzanne Fleischman (eds.), Modality in grammar and discourse, 473-502. Amsterdam: John Benjamins.

Frajzyngier, Zygmunt \& Robert Jasperson. 1991. That-clauses and other complements. Lingua 83(2-3). 133-153. 
Givón, Talmy. 1969. Studies in Chibemba and Bantu grammar. Los Angeles: University of California, Los Angeles dissertation.

Givón, Talmy. 2001. Syntax: Vol I: A functional-typological introduction. revised ed. Amsterdam: John Benjamins.

Güldemann, Tom. 2008. Quotative indexes in African languages: A synchronic and diachronic survey. Berlin: Mouton de Gruyter.

Hammarström, Harald, Robert Forkel \& Martin Haspelmath. 2018. Glottolog 3.3. Max Planck Institute for the Science of Human History. Jena. http://glottolog.org/ (22 August, 2018).

Haspelmath, Martin. 1999. On the cross-linguistic distribution of same-subject and differentsubject complement clauses: Economic vs. iconic motivation. Paper presented at ICLC, Stockholm.

Heine, Bernd \& Tania Kuteva. 2002. World lexicon of grammaticalization. Cambridge: Cambridge University Press.

Hengeveld, Kees. 1989. Layers and operators in Functional Grammar. Journal of Linguistics 25(1). 127-157.

Holvoet, Axel. 2016. Semantic functions of complementizers in Latvian. In Kasper Boye \& Petar Kehayov (eds.), Complementizer semantics in European languages (Empirical approaches to language typology 57), 225-264. Berlin: De Gruyter Mouton.

Horie, Kaoru. 2000. Complementation in Japanese and Korean. In Kaoru Horie (ed.), Complementation: Cognitive and functional perspectives, 11-31. Amsterdam: John Benjamins.

Kawalya, Deo, Gilles-Maurice de Schryver \& Koen Bostoen. 2018. Reconstructing the origins of the Luganda (JE15) modal auxiliaries -sóból- and -yînz-: a historicalcomparative study across the West Nyanza Bantu cluster. South African Journal of African Languages 38(1). 13-25.

Kawasha, Boniface. 2007. Subject-agreeing complementizers and their functions in Chokwe, Luchazi, Lunda and Luvale. Selected Proceedings of the 37th Annual Conference on African Linguistics. 180-190.

Kehayov, Petar \& Kasper Boye. 2016a. Complementizers in European languages: Overview and generalizations. In Kasper Boye \& Petar Kehayov (eds.), Complementizer semantics in European languages (Empirical approaches to language typology 57), 809-878. Berlin: De Gruyter Mouton.

Kehayov, Petar \& Kasper Boye. 2016b. Complementizers in European languages: An introduction. In Kasper Boye \& Petar Kehayov (eds.), Complementizer semantics in European languages (Empirical approaches to language typology 57), 1-11. Berlin: De Gruyter Mouton.

Kimenyi, Alexandre. 2018. The Multiple Syntagmatic Positions and Various Meanings and Functions of the Morpheme Nga in Bantu. http://www.kimenyi. com/the-nga-morphemein-bantu.php (26 August, 2018).

Lees, Robert B. 1960. The grammar of English nominalization. Bloomington, Indiana: University Research Center in Anthropology, Folklore, and Linguistics.

Lyons, John. 1977. Semantics. Cambridge: Cambridge University Press.

Meussen, Achille E. 1967. Bantu grammatical reconstructions. Africana Linguistica 3. 79121.

Murphy, John D. 1972. Luganda-English dictionary. Consortium Press for Catholic University of America Press.

Myers, Amy. 1975. Complementizer choice in selected Eastern Bantu languages. Proceedings of the Sixth Conference on African Linguistics. DSU WPL 20. 184- 193.

Nabirye, Minah. 2016. A corpus-based grammar of Lusoga. Gent: Universiteit Gent dissertation.

Nakayiza, Judith. 2013. The sociolinguistics of multilingualism in Uganda: A case study of the official and non-official language policy, planning and management of Luruuri- 
Lunyara and Luganda. London: School of Oriental \& African Studies (SOAS) dissertation.

Newmeyer, Frederick. 2015. Parentheticals and the grammar of complementation. In Stefan Schneider, Julie Glikman \& Mathieu Avanzi (eds.), Parenthetical verbs. Berlin: De Gruyter.

Noonan, Michael. 2007. Complex constructions. In Timothy Shopen (ed.), Language typology and syntactic description, vol.2, 52-150. Cambridge: Cambridge University Press.

Nurse, Derek. 2008. Tense and aspect in Bantu. Oxford: Oxford University Press.

Nurse, Derek \& Henry R. T. Muzale. 1999. Tense and aspect in Great Lakes Bantu languages. In Jean-Marie Hombert \& Larry Michael Hyman (eds.), Bantu historical linguistics: Theoretical and empirical perspectives, 517-544. Stanford: CSLI Publications. Palmer, Frank Robert. 1979. Modality and the English modals. London: Longman. Palmer, Frank Robert. 2001. Mood and modality. Cambridge: Cambridge University Press. Perkins, Mick R. 1983. Modal expressions in English. Frankfurt am Main: Peter Lang. Ransom, Evelyn N. 1986. Complementation, its meanings and forms. Amsterdam: John Benjamins.

Rentzsch, Julian \& Liljana Mitkovska. 2017. Complementation strategies with the verb 'know' in Balkan Turkish, Standard Turkish and Macedonian. Paper presented at 39th Annual Conference of the German Linguistic Society, March 8th-10th. Saarland University, Saarbrücken.

Schoenbrun, David L. 1994. Great Lakes Bantu: Classification and settlement chronology. Sprache und Geschichte in Afrika (15). 91-152.

Schüle, Susanne. 2000. Perception verb complements in Akatek, a Mayan language. Tübingen: University of Tübingen dissertation.

Serdobolskaya, Natalia. 2016. Semantics of complementation in Ossetic. In Kasper Boye \& Petar Kehayov (eds.), Complementizer semantics in European languages (Empirical approaches to language typology 57), 293-339. Berlin: De Gruyter Mouton.

Sørensen, Marie-Louise Lind. 2013. A cross-linguistic study of knowledge-predicate complementation. Copenhagen: University of Copenhagen MA thesis.

Sørensen, Marie-Louise Lind. 2018. The contrast between states-of-affairs and propositions in clausal complementation: Crosslinguistic perspectives. Copenhagen: University of Copenhagen dissertation.

Sørensen, Marie-Louise Lind \& Kasper Boye. 2015. Vidensprædikats-komplementering. Ny Forskning i Grammatik 22. 233-253.

Spronck, Stef. 2012. Minds divided. Speaker attitudes in quotatives. In Isabelle Buchstaller \& Ingrid van Alphen (eds.), Quotatives, cross-linguistic and crossdisciplinary perspectives, 71-113. John Benjamins.

Stassen, Leon. 1985. Comparison and universal grammar. Oxford: Blackwell.

Taylor, Charles V. 1985. Nkore-Kiga. London: Croom Helm.

Thompson, Sandra A. 2002. "Object complements" and conversation: Towards a realistic account. Studies in Language 26(1). 125-163.

Uganda Bureau of Statistics. 2016. The National Population and Housing Census 2014 Main Report. Tech. rep. Kampala.

Van de Velde, Mark. 2019. Nominal morphology and syntax. In Mark Van de Velde, Koen Bostoen, Derek Nurse \& Gérard Philippson (eds.), The Bantu languages, 2nd, 237-269. London: Routledge.

Van der Auwera, Johan \& Vladimir A. Plungian. 1998. Modality’s semantic map. Linguistic Typology 2. 79-144.

Verspoor, Marjolijn.2000. Iconicity in English complement constructions. In Kaoru Horie (ed.), Complementation: Cognitive and functional perspectives (Converging Evidence in Language and Communication Research 1). Amsterdam: John Benjamins. 
Witzlack-Makarevich, Alena, Saudah Namyalo, Anatol Kiriggwajjo, Zarina Molochieva \& Amos Atuhairwe. 2019. A corpus of spoken Ruuli. Kampala \& Jerusalem: Makerere University \& Hebrew University of Jerusalem.

Marie-Louise Lind Sørensen < marie-louise.sorensen@abo.fi> Åbo Akademi University

Turku, Finland

Alena Witzlack-Makarevich < witzlack@ googlemail.com> Hebrew University of Jerusalem Jerusalem, Israel. 